\title{
Expert Testimony on the Psychology of Confessions: A Pyramidal Framework of the Relevant Science
}

\author{
Saul M. Kassin
}

Increasingly, psychologists are being called to serve as consultants and expert witnesses in criminal cases involving coerced - and possibly false - confessions. ${ }^{1}$ In some instances, the main purpose is to assess a defendant's competence or vulnerability, an inquiry that brings into focus individual characteristics such as age, intelligence, mental health, criminal justice experience, and personality traits such as interrogative compliance and suggestibility. In other instances, the main purpose is to evaluate the social influence conditions under which the accused waived his or her Miranda rights and then confessed. This latter inquiry brings into play a number of foundational principles of psychology and, more specifically, social psychology.

The trials and tribulations of John Kogut, Dennis Halstead, and John Restivo are a case in point. In 1986, largely on the basis of his confession, Kogut and the two other young men that he had implicated were tried for the rape and murder of a 16-year-old girl. Two trials were held in Nassau County, New York, at which these defendants were convicted and sentenced to prison. They remained incarcerated for 17 years until DNA tests on the semen originally recovered from the victim's body conclusively excluded all three men, rendering the confession an inaccurate description of the crime. Through the

1 There is no way to determine the precise number of times that experts have testified on confessions because a record for appeal is created only in cases in which experts have been excluded or limited in their testimony (for a review, see Fulero, 2004). Through an informal, unpublished survey of 12 known experts in the area, which I conducted in 2005, I found that there were 335 reported instances of testimony in federal and military courts and in 36 different states (some were at suppression hearings; some at postconviction relief hearings; most in jury and bench trials). 


\section{Saul M. Kassin}

intervention of the Innocence Project, the convictions were vacated in 2003. Shortly afterward, however, the district attorney - unwilling to concede that the original confession was false, and despite the absence of additional evidence - decided to retry Kogut, the confessor.

If successful, the district attorney would have established a dangerous precedent, being the first to reconvict someone of a crime for which they had been exonerated by DNA evidence. In anticipation of this trial, Kogut's legal defense team, led by Centurion Ministries, proffered expert testimony on the psychology of confessions. The intended and circumscribed purpose of this testimony was not to offer an ultimate opinion as to whether the original confession had been true or false but to educate the judge or jury about general principles of relevance to making this assessment. The district attorney's office objected, arguing that the subject matter did not pass New York's criterion of "general acceptance" within the scientific community. The court thus granted a Frye hearing "to determine whether the methodology of social psychology was generally accepted and whether the voluntariness of the defendant's confession was a proper subject of expert testimony." Occurring through the spring and summer of 2005 , this hotly contested hearing contained testimony from 4 experts, took 12 days to complete, and generated 1,734 pages of transcript. It also attracted a great deal of news coverage (including a story by $\mathrm{ABC}$ Primetime) and was accompanied by a surprising press release in which the Nassau County district attorney advocated for the first time the videotaping of interrogations.

On September 15, 2005, Judge Victor Ort released an 11-page opinion in which he ruled that "... psychological studies on the voluntariness of confessions generally and the phenomenon of eliciting false confessions will be admissible at trial" (People of the State of New York v. Kogut, 2005, p. 10). The judge specifically concluded that the methodology and analysis are generally accepted within the field, and that jurors, who presume that innocent persons would not confess to crimes they did not commit, would benefit from the resulting testimony. Addressing the prosecutor's expert, the judge stated: "The fact that social psychology is not yet able to plot the curve showing the relationship between the decision to confess and the variables involved does not rebut the significance of Dr. Kassin's findings" (p. 9). ${ }^{2}$

2 Subsequent to this ruling, the defendant waived his right to a jury in favor of a bench trial. The expert testimony was admitted, as ruled, and the defendant was acquitted. At that point, the charges against Halstead and Restivo, the other men initially convicted and imprisoned because of Kogut's false confession, were dismissed. 
Different standards are used to determine the admissibility of expert testimony. In New York and several other states, the classic and conservative Frye test (1923) states that to be admissible expert testimony must conform to generally accepted principles within a discipline (Frye v. United States, 1923). The Federal Rules of Evidence (FRE), codified in 1975, shifted the emphasis, stating that expert testimony is admissible if the expert is qualified, if the testimony is reliable, and if the testimony assists the trier of fact. In Daubert $v$. Merrell Dow Pharmacenticals, Inc. (1993), the U.S. Supreme Court urged trial judges to serve as even more active gatekeepers of scientific evidence by ascertaining for themselves whether an expert proffers information that is scientific - as measured by such criteria as being testable, falsifiable, peer reviewed, reliable, valid, and generally accepted (for a discussion of Daubert and its implications, see Faigman \& Monahan, 2005).

Using the Frye hearing in the Kogut case as an illustration, this chapter is written with three objectives in mind. The first is to propose a three-tiered pyramidal framework for conceptualizing any body of relevant psychology. The second is to more fully develop this framework by illustrating its use in the psychology of interviewing, interrogation, the elicitation of confessions, and their consequences. The third objective is to address a relevant legal question concerning expert testimony that is extrinsic to this framework - a question concerning the extent to which expert testimony is needed or whether lay jurors are sufficiently informed as a matter of common sense.

\section{The Pyramid: General Framework}

It is both accurate and important to represent the corpus of expert knowledge on confessions in the form of a three-tiered pyramid - with individual cases at the vertex; relevant core principle of psychology at the base; and content-specific forensic research in the middle. Indeed, this three-tiered pyramidal framework brings to the forefront a means of depicting any body of knowledge and is implicit in all subdisciplines of forensic psychology. Whether the subject matter is eyewitness testimony, race or gender discrimination, rape trauma syndrome, or confessions, experts have routinely sought to link real-world instances of a phenomenon to basic principles of psychology and, when available, to research specifically aimed at hypothesis-testing in a particular context.

At the vertex, unconnected to science, are actual accounts of postconviction DNA exonerations, litigated acts of discrimination, instances 


\section{Saul M. Kassin}

of rape and other forms of crime victimization, and the like. As reported in books, newspapers, magazines, and television documentaries, these stories may shock the public conscience and reveal that these events occur, with some unknown frequency; that they share certain common features; and that they seem more common in some types of people and in some settings than in others. Knowing that concrete and vivid anecdotes are persuasive, psychological experts testifying in court will often use these accounts to illustrate key points.

Depending on the subject matter, individual case data can be derived from first- and secondhand case materials such as police reports, medical and forensic tests, trial testimony, employment records, and victim interviews from a single case. This is the part of the pyramid that is visible to the public, but without scientific explanation as to causes or correlates. Case studies have served an invaluable purpose in the history of psychology. Through the study of split brain patients, child prodigies, amnesiacs, great leaders, lucid dreamers, chess masters, and others who are exceptional in some way, the in-depth study of single cases has provided a basis for generating theories to be tested by more systematic means.

At the base of the pyramid is the warehouse of core psychological principles, research findings, and propositions. The product of theory testing, this warehouse contains the basic research of psychological science - from the nineteenth-century laws of psychophysics to twentyfirst century advances in the neuroimaging of perception and memory, the social-cognitive roots of stereotyping and prejudice, and the consequences of posttraumatic stress and other disorders. Designed for theory testing, the core is rich in context-free research collected in laboratory settings and built to maximize internal validity. It is common, in the early (some would say, "premature") growth stages of an applied science, for writers and expert witnesses to rely exclusively on core principles, leaping from the laboratory to the setting to be predicted. This was evident in the modern but early days of the eyewitness area, where experts testified about arousal, weapon focus, and the other-race bias on the basis of general theories of attention and memory, and basic laboratory experiments, even before these propositions had been tested in a forensic context.

The middle, linkage, part of the pyramid is always the last to develop within an applied science. Assuming the importance of the problem revealed by the cases at the vertex, and in recognition of the external validity limits inherent in the core principles and basic research, researchers interested in a forensic subdiscipline conduct contentspecific research that is inspired by actual cases and resembles in 
mundane ways the settings and behaviors in question. For example, in the eyewitness area, which is at a relatively advanced stage of maturity, this transition from a reliance on core principles to contentspecific research was seen, over the past quarter century, in the numerous studies by Wells and Lindsay and their colleagues, Malpass, Brigham, and others, and was marked by the shift from the study of estimator variables to system variables (Wells, 1978; for an historical overview, see Doyle, 2005). Currently, when experts testify about lineup composition, instructions, and presentation format, they do so by relying on realistic, content-specific forensic studies. At this point in the development of a domain, one might argue that this middle level of the pyramid renders the base less relevant.

\section{The Pyramid: Psychology of Confessions}

A three-tiered pyramidal framework can be used to depict any body of knowledge of relevance to forensic psychology. In the remainder of this chapter, the burgeoning study of police interviewing, interrogations, and confessions will be used to illustrate this framework (see figure 10.1; for more comprehensive reviews of this literature, see Gudjonsson, 1992, 2003; Kassin, 1997, 2005; Kassin \& Gudjonsson, 2004; Wrightsman \& Kassin, 1993).

\section{At the vertex: The archives of proven false confessions}

Beginning with the Salem witch trials of the seventeenth century, the landscape of American legal history is littered with erroneous convictions of innocent men and women who were prosecuted, wrongfully convicted, and sentenced to prison or death because of confessions to crimes they did not commit. There are four ways in which confessions are proved false: (1) It turns out that the confessed crime did not occur; (2) the real perpetrator is apprehended; (3) postconfession evidence reveals that the confessor's story was physically impossible; and (4) DNA or other exculpatory evidence was discovered.

Although numerous confessions have been proven false without dispute, a precise prevalence rate of the problem is not known, and is likely not knowable. What is clear, however, is that $12 \%$ of prisoners who were interrogated, $3-4 \%$ of college students, and $1-2 \%$ of older university students self-report having given false confessions to police (Gudjonsson, 2003); that 20-25\% of all DNA exonerations had 


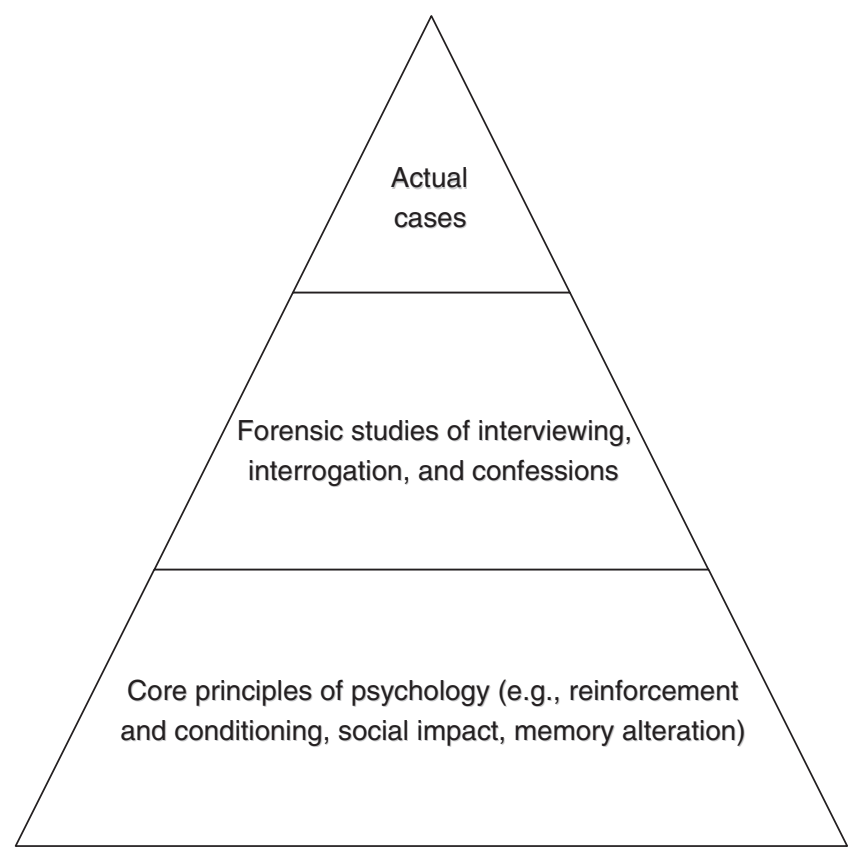

Figure 10.1 Pyramidal model of expert testimony on confessions

contained confessions in evidence (Scheck, Neufeld, \& Dwyer, 2000; www.innocenceproject.org/); Moreover, these discovered cases represent only the tip of a much larger iceberg, as they do not take into account the many false confessions that are quietly rejected by police or prosecutors before trial, false confessions to minor crimes that result in guilty pleas, and false confessions in juvenile proceedings that are confidential (Drizin \& Leo, 2004).

At the top of this pyramid are the horror stories of false confessions taken from juveniles and other vulnerable suspect populations and in the presence of prolonged detention and isolation, deprivation of needs, physical discomfort, implicit or explicit promises and threats, and various high-influence tactics of police interrogation. Over the years, case studies of this nature have proved useful in the development of this research area. By comparing and contrasting several known cases throughout history, for example, and by drawing on theories of social influence, Kassin and Wrightsman (1985) introduced a taxonomy that distinguished among three types of false confessions. Voluntary false confessions are self-incriminating statements offered without external pressure. Coerced-compliant false confessions are those in 
which a suspect confesses in order to escape an aversive interrogation, avoid an explicit or implied threat, or gain a promised or implied reward. This confession is a mere act of public compliance by a suspect who knows that he or she is truly innocent. Third, coercedinternalized false confessions are those in which an innocent but vulnerable person - in response to certain highly suggestive procedures - comes to believe that he or she committed the crime, sometimes forming a false memory in the process. This classification scheme has provided a useful framework for the study of false confessions and has been widely used and refined by others.

In short, the study of actual cases has proved informative, revealing that false confessions occur with some unknown frequency, in different ways, and for different reasons; that they share certain common features; and that they seem to be associated with the presence of some conditions, indicating potential risk factors, more than others. Of course, no analysis of these cases can afford conclusions concerning the causal nexus of factors associated with the elicitation of confessions.

\section{At the base: Relevant core principles of psychology}

In the scientific study of confessions, it is important for experts to communicate to the courts that our relevant knowledge is firmly grounded not only in content-specific research but in universally accepted core principles of psychology. This is an important point because opponents will try to force experts in this area to construe the field in the narrowest of terms - terms that exclude the 100-plus years of knowledge that forms the base of the pyramid.

Depending on the fact pattern of a particular case involving a disputed confession, there are numerous basic phenomena that may prove relevant - for example, pertaining to the effects of isolation, stress, alcohol, childhood and adolescence, false evidence, and the processing of pragmatic implications (as when leniency in exchange for confession is implied by minimization tactics). For example, the scientific research literature on sleep deprivation is relevant in a number of cases. In Kogut, the defendant had been interrogated for 15 hours when he signed the confession and for more than 18 hours when he appeared in a videotaped statement. Interrogated through the night, he had also not slept for close to 30 hours. Except for one study showing that interrogative suggestibility scores increase with prolonged sleep deprivation (Blagrove, 1996), no research has examined the effects of sleep deprivation on the behavior of suspects in the 


\section{Saul M. Kassin}

interrogation room. Nevertheless, there is a wealth of relevant empirical knowledge that is reliable and generally accepted. Across a range of cognitive, affective, and behavioral measures, including information processing and decision-making performance, studies of college students, medical interns, motorists, fighter pilots, and others have shown that sleep deprivation "strongly impairs human functioning" (Pilcher \& Huffcut, 1996; see also Harrison \& Horne, 2000).

In very general terms, it is reasonable to identify three broad, well-established sets of principles that are ripe for expert testimony on confessions - all of which are beyond dispute in the scientific community (this is by no means an exhaustive list). The first core principle, dating back to Thorndike's (1911) law of effect, is that people are highly responsive to reinforcement and subject to the laws of conditioning, and that behavior is influenced more by perceptions of short-term than long-term consequences, which are strategically manipulated by trained police investigators. Of distal relevance to a psychological analysis of interrogation are the thousands of operant animal studies of reinforcement schedules, punishment, and appetitive, avoidance, and escape learning, as well as behavioral modification applications in clinics, schools, and workplaces. Looking through a behavioral lens, one is struck by the ways in which interrogators shape suspects to confess to particular narrative accounts of crimes as if they were rats in a Skinner box (Skinner, 1938; Herrnstein, 1970).

Similarly relevant to an analysis of choice behavior in the interrogation room are studies of human decision-making in the behavioral economics paradigm. A voluminous body of research has shown that people make choices believed to maximize their wellbeing given the constraints they face, making the best of the situation they are in what Herrnstein has called the matching law (Herrnstein, Rachlin \& Laibson, 1997). With respect to a suspect's response to interrogation, studies on the discounting of rewards and costs show that people tend to be myopic and impulsive in their orientation, preferring outcomes that are immediate rather than delayed, the latter depreciating over time in their subjective value (Rachlin, 2000). This tendency is particularly evident in juvenile populations and among smokers and other substance users (e.g., Bickel, Odum, \& Madden, 1999; Kollins, 2003).

Rooted in the observation that people are inherently social beings, a second set of core principles is that individuals are highly vulnerable to influence from change agents who seek their compliance. Of direct relevance to an analysis of interrogation are the extensive literatures on attitudes and persuasion (Petty \& Cacioppo, 1986), informational 
and normative influences (e.g., Asch, 1956), the use of sequential request strategies, as in the foot-in-the-door effect (Cialdini, 2001), and the gradual escalation of commands, issued by figures of authority, to effectively obtain self- and other-defeating acts of obedience (Milgram, 1974). Conceptually, Latane's (1981) social impact theory provides a coherent predictive model that can account for the influence of police interrogators - who bring power, proximity, and number to bear on their exchange with suspects (for a range of social psychological perspectives on interrogation, see Bem, 1966; Zimbardo, 1967; Davis \& O'Donohue, 2003).

A third set of core principles consists of the "seven sins of memory" that Schacter (2001) has identified from cognitive and neuroscience research - a list that includes memory transience, misattribution effects, suggestibility, and bias. When Kassin and Wrightsman (1985) first identified coerced-internalized false confessions, they were puzzled. At the time, existing models of memory could not account for the phenomenon whereby innocent suspects would come to internalize responsibility for crimes they did not commit. These cases occur when a suspect is dispositionally or situationally rendered vulnerable to manipulation and the interrogator then misrepresents the evidence, a common ploy. In light of a now extensive research literature on misinformation effects and the creation of illusory memories (e.g., Loftus, 1997, 2005), and a source monitoring perspective to explain how people, once confused, can be induced to distort their recollections, experts can now better grasp the process by which people internalize guilt for a crime they did not commit and the conditions under which this may occur (see Henkel \& Coffman, 2004).

\section{In the middle: Content-specific forensic research}

In recent years, increasing numbers of researchers have begun to conduct content-specific forensic research on the processes of interviewing and interrogation and the elicitation of confessions.

As one would expect, multiple methods are used to investigate this chain of events in the criminal justice system. Leo and Ofshe (1998) used an aggregated case study method to compare and contrast 60 proven or probable false confession cases. More recently, Drizin and Leo (2004) analyzed 125 proven false confession cases in the United States, occurring between 1971 and 2002, the largest sample ever studied. Leo (1996a), in the United States, and Moston, Stephenson, and Williamson (1992), in Great Britain, used naturalistic observations to study processes and outcomes in live and videotaped police 


\section{Saul M. Kassin}

interrogations. Gudjonsson $(1992,2003)$ and his colleagues have also used self-report methods to examine correlations between various personal suspect characteristics - such as interrogative compliance and suggestibility - and the tendency to confess or resist confession. My colleagues and I have developed experimental paradigms to test specific causal hypotheses about interrogation tactics that increase the risk of false confessions (e.g., Kassin \& Kiechel, 1996; Russano, Meissner, Narchet, \& Kassin, 2005) - and, more recently, to assess how accurately investigators make preinterrogation judgments of truth and deception (Meissner \& Kassin, 2002; Kassin, Meissner \& Norwick, 2005).

What follows is a brief overview of a research literature that is characterized by eclectic methods that have produced convergent results. Specifically, this overview examines four steps in the chain of events:

1. the accuracy with which police investigators make judgments of truth and deception from suspect interviews;

2. the Miranda warning and waiver, a process by which police apprise suspects of their rights to silence and counsel and elicit a waiver of these rights;

3. the interrogation, a process of social influence in which police employ various techniques to elicit confessions, sometimes by people who are innocent; and

4. the consequences of confession evidence as later evaluated by police, prosecutors, judges, and juries.

Interview-based truth and deception judgments. In countless numbers of false confessions, the police chose to interrogate an innocent person because they had made an incorrect judgment, based on an initial interview, that he or she was lying and hence culpable. Thomas Sawyer had blushed and looked away; Peter Reilly, Gary Gauger, and Michael Crowe exhibited too little emotion; Jeffrey Deskovic seemed overly distraught; Timothy Bickel broke down and cried. Many law enforcement professionals are trained to use these common-sense types of cues. For example, Inbau, Reid, Buckley, and Jayne (2001), authors of the well-known and widely used manual Criminal Interrogations and Confessions (4th edition), advise investigators to use various verbal cues (e.g., qualified or rehearsed responses), nonverbal cues (e.g., gaze aversion, frozen posture, slouching), and "behavioral attitudes" (e.g., unconcerned, anxious, guarded) to identify deception. Using these cues, they claim that investigators can be trained to judge truth and deception at an $85 \%$ level of accuracy. 
Despite popular conceptions, deception detection research has failed to support the claim that groups can attain such high average levels of performance. Most experiments have shown that people on average perform at no better than chance level - regardless of professional experience or training (for reviews of this literature, see Bond \& DePaulo, 2006; Granhag \& Strömwall, 2004; Vrij, 2000). One might argue that performance in the laboratory is poor because of the low-stakes nature of the task, which weakens deception cues (DePaulo et al., 2003). However, forensic studies using high-stake lies have produced mixed results, with one study suggesting that police can sometimes make these judgments at modestly high levels of accuracy (Mann, Vrij, \& Bull, 2004). One might also argue that professionals would be more accurate if they were to personally conduct the interviews rather than merely observe the sessions. However, research fails to support this notion as well (Buller, Strzyzewski, \& Hunsaker, 1991; Hartwig, Granhag, Strömwall, \& Vrij, 2004).

A number of studies have examined whether special training increases judgment accuracy in a specifically forensic context. Kassin and Fong (1999) trained some college students but not others in the Reid technique of lie detection and then presented videotaped denials of mock suspects who were truly guilty or innocent of a mock crime. As in studies in nonforensic settings, observers performed at no better than chance level - and those who underwent training were less accurate than naïve controls (though they were more confident and exhibited a response bias toward seeing deception). In a follow-up study, Meissner and Kassin (2002) administered the same task to experienced investigators from the United States and Canada, many of whom had received special training, and found that investigators - compared to college students - exhibited lower (chance-level) accuracy, significantly higher confidence, and a response bias toward deception. Similar results have been obtained with law enforcement samples in England (Vrij \& Mann, 2001), Israel (Elaad, 2003), Spain (Garrido, Masip, \& Herrero, 2004), and Sweden (Hartwig et al., 2004).

Miranda warnings and waivers. For suspects who are judged deceptive, the questioning becomes highly confrontational. There is, however, one procedural safeguard to protect the accused from this transition. In Miranda v. Arizona (1966), the U.S. Supreme Court ruled that police must inform all suspects placed in custody of their Constitutional rights to silence and to counsel - and suspects must voluntarily, knowingly, and intelligently waive these rights (for a review of the legal status of Miranda, see White, 2003). 


\section{Saul M. Kassin}

Research suggests two reasons why Miranda may not afford the protection it was supposed to provide. The first is that many juvenile suspects (Grisso, 1981; Oberlander \& Goldstein, 2001) and adults who are cognitively limited (Fulero \& Everington, 1995) do not fully comprehend or know how to apply these rights. Second, naturalistic observations reveal that a vast majority of suspects voluntarily waive their rights and submit to questioning (Leo, 1996b; Moston, Stephenson, \& Williamson, 1993).

This latter tendency may be most characteristic of innocents who stand falsely accused. Replicating a result previously observed in Great Britain, Leo (1996b) found that individuals with no prior record are more likely to waive their rights than are those who have criminal justice "experience." In light of recidivism rates in criminal behavior, this difference suggests that innocent people in particular are at risk to waive their rights. To test this hypothesis in a controlled setting, Kassin and Norwick (2004) had participants commit or not commit a mock theft of $\$ 100$, after which they were apprehended for investigation. Motivated to avoid further commitments of time without compensation, they were confronted by a male "detective" who sought a waiver of their Miranda rights. As predicted, participants who were innocent were substantially more likely to sign a waiver than those who were guilty (81\% to $36 \%$ ). Asked to explain their decisions, most innocents said afterward that they waived their rights precisely because they were innocent (e.g., "I did nothing wrong," "I didn't have anything to hide").

Social influences in the interrogation room. By definition, interrogation is an accusatory process of influence purposefully designed by a person in authority to elicit a confession from a suspect who is presumed guilty. For innocent people initially misjudged, one would hope that investigators would remain open-minded and reevaluate their beliefs. However, a great deal of research suggests that once people form an impression, they unwittingly seek, interpret, and create behavioral data in self-verifying ways. This last phenomenon - variously referred to by the terms self-fulfilling prophecy, interpersonal expectancy effect, and behavioral confirmation bias - was demonstrated by Rosenthal and Jacobson (1968) in their classic field study of teacher expectancy effects, with similar results later obtained not only in the laboratory (e.g., Snyder \& Swann, 1978) but in military, business, and other organizational settings (McNatt, 2000).

Importing the laboratory paradigm to the study of police interrogations, Kassin, Goldstein and Savitsky (2003) led student interrogators 
to believe that they would be questioning someone who was likely guilty or innocent of a mock crime. Then they randomly paired these interrogators with suspects who were actually guilty or innocent. Overall, those who were led to expect guilt asked more guiltpresumptive questions, used more techniques, exerted more pressure to get a confession, and made innocent suspects sound more anxious and defensive to observers. They (as well as neutral observers who later listened to the interviews on tape) were later more likely to see these suspects in incriminating terms. The presumption of guilt, which underlies interrogation, thus unleashed a process of behavioral confirmation, shaping the interrogator's behavior, the suspect's behavior, and ultimately the judgments of neutral observers.

In general terms, it is clear that police interrogation is a guilt-presumptive process that can set into motion a range of cognitive and behavioral confirmation biases. But it is also important to assess the specific techniques that are employed that may lead people to confess to crimes they did not commit. As derived from popular training manuals (Inbau et al., 2001), and as seen in practice (e.g., Leo, 1996a; Leo et al., 2006), modern police interrogations are conducted in a sequence of steps, essentially reducible to three processes: (1) isolation, often in a special interrogation room, which increases anxiety and the incentive to escape; (2) confrontation, in which the suspect is accused of the crime, presented with evidence, real or manufactured, and blocked from denial; and (3) minimization, in which the crime is morally excused by a sympathetic interrogator, leading suspects to see confession as a possible means of gaining leniency (see Kassin, 1997, 2005).

As noted earlier, a long history of psychological science indicates without dispute that people are responsive to reinforcement and conditioning, influenced more by perceptions of immediate than delayed consequences, and vulnerable to influence from social impact agents who use sequential request strategies and authority to elicit selfdefeating acts of compliance. With regard to studies specifically aimed at testing the tactics of interrogation, two lines of research in particular have implicated tactics that put innocent people at risk to confess.

The first tactic pertains to the presentation of false evidence. Once suspects are isolated, interrogators confront them with bold assertions of guilt, a process that may even involve misrepresentations of the evidence (e.g., pretending to have the suspect's fingerprints, a blood or hair sample, and eyewitness identification, or a failed polygraph). In the United States, this false evidence ploy is permissible (Frazier v. Cupp, 1969). It is perhaps not surprising that although this tactic 


\section{Saul M. Kassin}

is infrequently used (Leo, 1996a; Leo et al., 2006), it can be seen in virtually all proven false confession cases. Crime suspects report that their perception of the strength of the evidence was their primary reason for confession or denial (Moston et al., 1992). Moreover, laboratory experiments have shown that false evidence can lead innocent people to confess to acts they did not commit. In the first such study, college students engaged in a typing and reaction time task were accused of causing the experimenter's computer to crash by pressing a key they were instructed to avoid, and were asked to sign a confession (Kassin \& Kiechel, 1996). All participants were innocent and all initially denied the charge. In some sessions, a confederate told the experimenter that she witnessed the participant hit the forbidden key; in others she said she did not witness what happened. This false evidence significantly increased the number of students who signed a written confession, from $48 \%$ to $94 \%$ (this manipulation also increased the number of participants who internalized responsibility for this outcome they did not produce). Follow-up studies have replicated this effect, even when the confession was said to bear a financial consequence (Horselenberg, Merckelbach, \& Josephs, 2003; Horselenberg et al., 2006), and particularly among juveniles who are more compliant and more suggestible than adults (Redlich \& Goodman, 2003).

A second tactic that has received research attention concerns the use of minimization. Once interrogators have thrust a suspect into feeling trapped by evidence, they begin to suggest that the crime was spontaneous, accidental, provoked, drug-induced, or otherwise justified by circumstances. Over the years, most courts have rejected as involuntary confessions taken by promises of leniency, acknowledging the risk to innocent people. But what about promises that are implied, even if not spoken? In one study, readers of an interrogation transcript in which the interrogator made minimizing remarks inferred by pragmatic implication that leniency in sentencing would follow from confession, even without an explicit promise (Kassin \& McNall, 1991).

In a second study, a laboratory paradigm was used to assess the behavioral effects of minimization on the elicitation of true and false confessions (Russano et al., 2005). Participants were paired with a confederate for a problem-solving study and half were induced by that confederate to cheat by collaborating on a problem that was supposed to be solved alone. The experimenter "discovered" the similarity in the solutions, accused the participant of cheating, and tried to extract a signed confession by promising leniency, making minimizing remarks, 
using both tactics, or using no tactics. Overall, the confession rate was higher among guilty than innocent when leniency was promised than when it was not, and when minimization was used than when it was not. On calculations of diagnosticity (as measured by the ratio of true to false confessions), the results showed that diagnosticity was highest in the no-tactics cell (where $46 \%$ of guilty suspects confessed vs. only $6 \%$ of innocents) and that minimization - just like an explicit offer of leniency - reduced diagnosticity by tripling the rate of false confessions ( $81 \%$ vs. $18 \%$ ). In short, minimization serves as the implicit functional equivalent to a promise of leniency, putting innocents at risk to make false confessions.

Consequences of confession evidence in court. A fourth line of inquiry concerns the credibility and impact of confessions - first on police and prosecutors, but ultimately on judges and juries. In cases involving a disputed confession, a preliminary hearing is held for a judge to determine its voluntariness and admissibility. In American courts, confessions deemed voluntary are then admitted to the jury (with or without special instruction). The question is, with what effect?

Research on the impact of confessions throughout the criminal justice system is not encouraging. Mock jury studies have shown that confessions have more impact than eyewitness and character testimony, other potent forms of human evidence (Kassin \& Neumann, 1997). Moreover, people trust confessions and do not fully discount them even when it is logically and legally appropriate to do so. For example, Kassin and Sukel (1997) presented mock jurors with one of three versions of a murder trial: one that contained a low-pressure confession, a second that contained a high-pressure confession, and a third that lacked a confession. Faced with the high-pressure confession, participants appeared to respond in the legally prescribed manner, as assessed by two measures: Relative to those in the low-pressure condition, they judged the statement to be involuntary and said it did not influence their decisions. Yet on the all-important measure of verdicts, these confessions, which should have been discounted, significantly boosted the conviction rate.

Archival analyses of criminal justice statistics provide real-world corroboration of this disturbing pattern. When proven false-confessors have pled not guilty and proceeded to trial, the jury conviction rates have ranged from 73\% (Leo \& Ofshe, 1998) to 81\% (Drizin \& Leo, 2004). These figures led Drizin and Leo (2004) to describe confession evidence as "inherently prejudicial and highly damaging to a defendant, even if it is the product of coercive interrogation, even if it is 
supported by no other evidence, and even if it is ultimately proven false beyond any reasonable doubt" (p. 959).

\section{Outside the Pyramid: Factoring In "Common Knowledge"}

Both the Frye test of general acceptance and the more recent Daubert criteria, for assessing the validity of scientific, technical or other specialized knowledge, can be sufficiently addressed within the threetiered pyramidal framework. To address the more extrinsic question of whether an expert's testimony will assist the trier of fact - apart from how generally accepted and valid it may be - requires additional inquiry into the realm of common-sense psychology.

In recent years American courts have struggled with this question in a number of cases. In People of the State of New York v. Kogut (2005), Judge Ort noted that jurors may benefit from expert testimony even if they know in general terms that police interrogation is psychologically oriented. Drawing a parallel to the eyewitness area, the judge stated: "As with psychological studies of eyewitness identification, it cannot be said that the typical juror is familiar with psychological research concerning the voluntariness of confessions or the tendency of certain techniques to contribute to a false confession" (p. 9).

Another recent case is also instructive on this point. In United States v. Belyea (2005), the defendant confessed to the theft of a firearm after being terrified into thinking that the weapon was used in a murder, that his fingerprints were on it, and that he could avoid jail by cooperating (the confession contradicted subsequently discovered key details of the crime). The defendant moved to introduce expert trial testimony on false confessions, but the district court rejected this motion because "Jurors [already] know people lie." Belyea was convicted, but the U.S. Court of Appeals for the Fourth Circuit overturned the verdict, noting that the law requires a nuanced analysis of whether expert testimony would be useful in a particular case. Specifically, the Court argued that whereas jurors know that people lie, they may not know that certain people under certain conditions will confess, against their own self-interest, to crimes they did not commit. In this Court's judgment, "The phenomenon of false confessions is counterintuitive and is not necessarily explained by the general proposition that "jurors know people lie" " (p. 10).

It is beyond the scope of this chapter to discuss lay theories of reinforcement and motivation, human decision-making, truth and lie 
detection, and other issues of potential relevance to expert testimony in this area. In general, however, it seems clear that there are few, if any, phenomena of human behavior that are less intuitive than that of false confessions. Indeed, all confession-based wrongful convictions are a product of two problems: the first being that innocent people can be led to confess, the second being that police detectives, prosecutors, judges, and juries routinely believe these false confessions.

There are three bases for pessimism on the question of whether jurors are sufficiently equipped to evaluate confession evidence without assistance. First, generalized common sense leads us to trust confessions, a behavior that breaches self-interest in a profound way (most people believe they would never confess to a crime they did not commit and they cannot image the circumstances under which anyone would do so). Over the years, social psychologists have found in a wide range of contexts that people fall prey to the "fundamental attribution error" - that is, they tend to make dispositional attributions for a person's actions, taking behavior at face value, while neglecting the role of situational factors (Ross, 1977; Jones, 1990; Gilbert \& Malone, $1995)$. This tendency to underestimate social impact was seen in dramatic form when Milgram (1974) found that people vastly underpredicted the percentage of subjects who would exhibit total obedience in his experiment. Illustrating this point in a forensic context are studies showing that mock juries are corrupted by confessions regardless of whether they judge them to be voluntary or coerced (e.g., Kassin \& Sukel, 1997). Hence, it comes as no surprise that in actual cases, false-confessors who proceed to trial are usually convicted (Leo \& Ofshe, 1998; Drizin \& Leo, 2004).

A second basis for pessimism is that people are typically not adept at deception detection. Even professional lie catchers are accurate in only $45-60 \%$ of judgments, with a mean of $54 \%$ (Vrij, 2000). We saw earlier that neither trained college students nor experienced police investigators can accurately separate true from false denials. But what about the assumption that "I'd know a false confession if I saw one?" In a two-part study, Kassin et al. (2005) videotaped male prison inmates giving two narrative confessions: one to the crime for which they were in prison, a second to a crime that they did not commit. Then we created a stimulus videotape containing 10 different inmates, each giving a single true or false confession to one of five crimes. The result was that neither college students nor police investigators performed significantly better than chance, though police were significantly more confident in their judgments and exhibited significantly more false alarms in their errors. 


\section{Saul M. Kassin}

A third basis for pessimism is that police-induced confessions, unlike other types of verbal statements, are corrupted by the very process of interrogation that elicits them - designed for persuasion, even if false. In most documented false confessions, the statements ultimately presented in court are compelling, often containing vivid and accurate details about the crime. Sometimes these details had become known to the innocent suspect through leading questions, photographs, visits to the crime scene, and other secondhand sources of information. To further obfuscate matters, many false confessions contain statements of motivation, apologies and expressions of remorse, and even physical reenactments. In some cases, innocent suspects correct minor errors that appear in the statements, corrections that interrogators are trained to insert and get corrected for tactical purposes. Hence, to the naïve juror, false confessions often appear to be voluntary, textured with detail, and the product of personal experience - not staged, rehearsed, and enacted, as they are, like a Hollywood drama (Kassin, 2002).

This point is clearly illustrated in the case of John Kogut, who was exonerated by DNA after 17 years in prison, retried on his original confession, and acquitted. The confession Kogut had signed contained a striking degree of colorful detail, not only on central aspects of the murder, but on peripheral details as well - such as a description of the victim's "gold colored chain with what looked like a double heart on it with a piece broken off of it." 3 The statement Kogut signed also contained errors that he presumably corrected and initialed. Yet at trial, his interrogator admitted that he inserted the errors, made the corrections, and directed Kogut to initial these corrections.

\section{Using Psychology to Promote Justice}

Voluntarily or under pressure, it is inevitable that people will sometimes confess to crimes they did not commit, thus placing the burden on the courts to serve as a safety net. Yet judges and juries cannot be expected to intuit as a matter of common knowledge the relevant research literatures on reinforcement and conditioning, human decision-making, reconstructive memory, social influence, and other core

3 The confession was handwritten by one of the interrogators and signed by Kogut. Importantly, this statement contained no information that was not already known to police and led police to no evidence they did not already have. 
principles that define the 100-plus years of psychological science. Predictable by studies of the fundamental attribution error, it is particularly clear that people accept confessions uncritically, even when coerced. Toward this end, expert testimony provides a necessary mechanism for assisting juries to more accurately assess this evidence - and how and from whom it was produced.

Another important mechanism is to ensure that trial judges, juries, and appellate courts can observe the process by which confessions are produced. In Great Britain, the Police and Criminal Evidence Act of 1986 mandated that all custodial sessions be taped in their entirety. In the United States, five states (Minnesota, Alaska, Illinois, Maine, and Wisconsin) and the District of Columbia presently have mandatory videotaping requirements, though the practice is found elsewhere on a voluntary basis. ${ }^{4}$

There are many advantages to a videotaping policy (e.g., the presence of a camera should deter interrogators from using coercive tactics; disable frivolous defense claims of coercion; and provide a full and accurate record of the transaction, a common source of dispute in courts). For the purpose of the current discussion, the following hypothesis presents itself: A mandatory videotaping policy will increase the fact finding accuracy of judges and juries. In ruling on voluntariness, judges will observe firsthand the suspect's physical and mental state, the conditions of interrogation, and the tactics that were used; and juries, in rendering a verdict, will observe not only how the statements were taken but from whom the crime details, if accurate, originated.

As a matter of policy, it is important not only that entire sessions be recorded but that the camera adopt a neutral "equal-focus" perspective that shows both the accused and his or her interrogators. In a series of studies on illusory causation effects, Lassiter and his colleagues found that people are more attuned to the situational factors that draw confessions when the interrogator is on camera than when the sole focus is on the suspect (for a review, see Lassiter \& Geers, 2004). Under these former circumstances, juries make more informed judgments of voluntariness and guilt when they see not only the final confession but the conditions that prompted it and the source of the details that it contained (Lassiter, Geers, Handley, Weiland, \& Munhall, 2002).

4 In Commonwealth of Massachusetts v. DiGiambattista (2004), the Supreme Judicial Court of Massachusetts stopped short of a mandatory videotaping requirement but ruled that any confession resulting from an unrecorded interrogation will entitle the defendant to a jury instruction that urges caution in the use of that confession. 


\section{Saul M. Kassin}

\section{REFERENCES}

Asch, S. E. (1956). Studies of independence and conformity: A minority of one against a unanimous majority. Psychological Monographs, 70, 416.

Bem, D. J. (1966). Inducing belief in false confessions. Journal of Personality and Social Psychology, 3, 707-710.

Bickel, W. K., Odum, A. L., \& Madden, G. L. (1999). Impulsivity and cigarette smoking: Delay discounting in current, never, and ex-smokers. Psychopharmacology, 146, 447-454.

Blagrove, M. (1996). Effects of length of sleep deprivation on interrogative suggestibility. Journal of Experimental Psychology: Applied, 2, 48-59.

Bond, C. F., Jr., \& DePaulo, B. M. (2006). Accuracy of deception judgments. Personality and Social Psychology Review, 10, 214-234.

Buller, D. B., Strzyzewski, K. D., \& Hunsaker, F. G. (1991). Interpersonal deception: II. The inferiority of conversational participants as deception detectors. Communication Monographs, 58, 25-40.

Cialdini, R. B. (2001). Influence: Science and practice (4th ed.). Needham Heights, MA: Allyn \& Bacon.

Commonwealth of Massachusetts v. DiGiambattista, 442 Mass. 423 (2004).

Daubert v. Merrell Dow Pharmaceuticals, Inc., 509 U.S. 579 (1993).

Davis, D., \& O'Donohue, W. (2003). The road to perdition: "Extreme influence" tactics in the interrogation room. In W. O'Donohue, P. Laws, \& C. Hollin (Eds.), Handbook of forensic psychology (pp. 897-996). New York: Basic Books.

DePaulo, B. M., Lindsay, J. J., Malone, B. E., Muhlenbruck, L., Charlton, K., \& Cooper, H. (2003). Cues to deception. Psychological Bulletin, 129, 74-112.

Doyle, J. M. (2005). True witness: Cops, courts, science, and the battle against misidentification. New York: Palgrave Macmillan.

Drizin, S. A., \& Leo, R. A. (2004). The problem of false confessions in the post-DNA world. North Carolina Law Review, 82, 891-1007.

Elaad, R. (2003). Effects of feedback on the overestimated capacity to detect lies and the underestimated ability to tell lies. Applied Cognitive Psychology, 17, 349-363.

Faigman, D. L., \& Monahan, J. (2005). Psychological evidence at the dawn of the law's scientific age. Annual Review of Psychology, 56, 631-659.

Frazier v. Cupp, 394 U.S. 731 (1969).

Frye v. United States, 293 F. 1013 (D.C. Circuit, 1923).

Fulero, S. M. (2004). Expert psychological testimony on the psychology of interrogations and confessions. In G. D. Lassiter (Ed.), Interrogations, confessions, and entrapment (pp. 247-263). New York: Kluwer Academic.

Fulero, S. M., \& Everington, C. (1995). Assessing competency to waive Miranda rights in defendants with mental retardation. Law and Human Behavior, 19, 533-543. 
Garrido, E., Masip, J., \& Herrero, C. (2004). Police officers credibility judgments: Accuracy and estimated ability. International Journal of Psychology, 39, 254-275.

Gilbert, D. T., \& Malone, P. S. (1995). The correspondence bias. Psychological Bulletin, 117, 21-38.

Granhag, P. A., \& Strömwall, L. (Eds.) (2004). Deception detection in forensic contexts. Cambridge, England: Cambridge University Press.

Grisso, T. (1981). Juveniles' waiver of rights: Legal and psychological competence. New York: Plenum.

Gudjonsson, G. H. (1992). The psychology of interrogations, confessions, and testimony. London: Wiley.

Gudjonsson, G. H. (2003). The psychology of interrogations and confessions: $A$ handbook. Chichester, England: John Wiley \& Sons.

Harrison, Y., \& Horne, J. A. (2000). The impact of sleep deprivation on decision making: A review. Journal of Experimental Psychology: Applied, 6, 236-249.

Hartwig, M., Granhag, P. A., Strömwall, L. A., \& Vrij, A. (2004). Police officers' lie detection accuracy: Interrogating freely vs. observing video. Police Quarterly, 7, 429-456.

Henkel, L. A., \& Coffman, K. J. (2004). Memory distortions in coerced false confessions: A source monitoring framework analysis. Applied Cognitive Psychology, 18, 567-588.

Herrnstein, R. J. (1970). On the law of effect. Journal of the Experimental Analysis of Behavior, 7, 243-266.

Herrnstein, R. J., Rachlin, H., \& Laibson, D. I. (Eds.) (1997). The matching law: Papers in psychology and economics. New York: Russell Sage Foundation.

Horselenberg, R., Merckelbach, H., \& Josephs, S. (2003). Individual differences and false confessions: A conceptual replication of Kassin \& Kiechel (1996). Psychology, Crime and Law, 9, 1-18.

Horselenberg, R., Merckelbach, H., Smeets, T., Franssens, D., Ygram Peters, G-J., \& Zeles, G. (2006). False confessions in the lab: Do plausibility and consequences matter? Psychology, Crime and Law, 12, 61-75.

Inbau, F. E., Reid, J. E., Buckley, J. P., \& Jayne, B. C. (2001). Criminal interrogation and confessions (4th ed.). Gaithersberg, MD: Aspen. www.innocenceproject.org/

Jones, E. E. (1990). Interpersonal perception. New York: Freeman.

Kassin, S. M. (1997). The psychology of confession evidence. American Psychologist, 52, 221-233.

Kassin, S. M. (2002, November 1). False confessions and the jogger case. New York Times, p. A31.

Kassin, S. M. (2005). On the psychology of confessions: Does innocence put innocents at risk? American Psychologist, 60, 215-228.

Kassin, S. M., \& Fong, C. T. (1999). "I'm innocent!" Effects of training on judgments of truth and deception in the interrogation room. Law and Human Behavior, 23, 499-516. 


\section{Saul M. Kassin}

Kassin, S. M., Goldstein, C. J., \& Savitsky, K. (2003). Behavioral confirmation in the interrogation room: On the dangers of presuming guilt. Law and Human Behavior, 27, 187-203.

Kassin, S. M., \& Gudjonsson, G. H. (2004). The psychology of confession evidence: A review of the literature and issues. Psychological Science in the Public Interest, 5, 35-69.

Kassin, S. M., \& Kiechel, K. L. (1996). The social psychology of false confessions: Compliance, internalization, and confabulation. Psychological Science, 7, 125-128.

Kassin, S. M., \& McNall, K. (1991). Police interrogations and confessions: Communicating promises and threats by pragmatic implication. Law and Human Behavior, 15, 233-251.

Kassin, S. M., Meissner, C. A., \& Norwick, R. J. (2005). "I'd know a false confession if I saw one": A comparative study of college students and police investigators. Law and Human Behavior, 29, 211-227.

Kassin, S. M., \& Neumann, K. (1997). On the power of confession evidence: An experimental test of the "fundamental difference" hypothesis. Law and Human Behavior, 21, 469-484.

Kassin, S. M., \& Norwick, R. J. (2004). Why suspects waive their Miranda rights: The power of innocence. Law and Human Behavior, 28, 211-221.

Kassin, S. M., \& Sukel, H. (1997). Coerced confessions and the jury: An experimental test of the "harmless error" rule. Law and Human Behavior, $21,27-46$.

Kassin, S. M., \& Wrightsman, L. S. (1985). Confession evidence. In S. Kassin \& L. Wrightsman (Eds.), The psychology of evidence and trial procedure (pp. 67-94). Beverly Hills, CA: Sage.

Kollins, S. H. (2003). Delay discounting is associated with substance use in college students. Addictive Behaviors, 28, 1167-1173.

Lassiter, G. D., \& Geers, A. L. (2004). Evaluation of confession evidence: Effects of presentation format. In G. D. Lassiter (Ed.), Interrogations, confessions, and entrapment. New York: Kluwer Press.

Lassiter, G. D., Geers, A. L., Handley, I. M., Weiland, P. E., \& Munhall, P. J. (2002). Videotaped confessions and interrogations: A change in camera perspective alters verdicts in simulated trials. Journal of Applied Psychology, $87,867-874$.

Latane, B. (1981). The psychology of social impact. American Psychologist, $36,343-356$.

Leo, R. A. (1996a). Inside the interrogation room. The Journal of Criminal Law and Criminology, 86, 266-303.

Leo, R. A. (1996b). Miranda's revenge: Police interrogation as a confidence game. Law and Society Review, 30, 259-288.

Leo, R. A., Kassin, S. M., Richman, K. D., Colwell, L. H., Leach, A., La Fon, D., \& Meissner, C. (2006). Police interviewing and interrogation: A national self-report survey of police practices and beliefs. Paper presented at the American Psychology-Law Society, St. Petersburg, FL. 
Leo, R. A., \& Ofshe, R. J. (1998). The consequences of false confessions: Deprivations of liberty and miscarriages of justice in the age of psychological interrogation. Journal of Criminal Law and Criminology, 88, 429-496.

Loftus, E. F. (1997). Creating false memories. Scientific American, 277, 70-75.

Loftus, E. F. (2005). Planting misinformation in the human mind: A 30-year investigation of the malleability of memory. Learning \& Memory, 12, 361-366.

Mann, S., Vrij, A., \& Bull, R. (2004). Detecting true lies: Police officers' ability to detect suspects' lies. Journal of Applied Psychology, 89, 137-149.

McNatt, D. B. (2000). Ancient Pygmalion joins contemporary management: A meta-analysis of the result. Journal of Applied Psychology, 85, 314-322.

Meissner, C. A., \& Kassin, S. M. (2002). "He's guilty!": Investigator bias in judgments of truth and deception. Law and Human Behavior, 26, $469-480$.

Milgram, S. (1974). Obedience to authority: An experimental view. New York: Harper \& Row.

Miranda v. Arizona, 384 U.S. 336 (1966).

Moston, S., Stephenson, G. M., \& Williamson, T. M. (1992). The effects of case characteristics on suspect behaviour during questioning. British Journal of Criminology, 32, 23-40.

Moston, S., Stephenson, G. M., \& Williamson, T. M. (1993). The incidence, antecedents and consequences of the use of the right to silence during police questioning. Criminal Behavior and Mental Health, 3, 30-47.

Oberlander, L. B., \& Goldstein, N. E. (2001). A review and update on the practice of evaluating Miranda comprehension. Behavioral Sciences and the Law, 19, 453-471.

People of the State of New York v. Kogut (2005). Supreme Court of Nassau County, Unpublished opinion, Indictment No. 61029/85, September 15, 2005.

Petty, R. E., \& Cacioppo, J. T. (1986). Communication and persuasion: Central and peripheral routes to attitude change. New York: Springer-Verlag.

Pilcher, J. J., \& Huffcut, A. (1996). Effects of sleep deprivation on performance: A meta-analysis. Sleep, 19, 318-326.

Rachlin, H. (2000). The science of self-control. Cambridge, MA: Harvard University Press.

Redlich, A. D., \& Goodman, G. S. (2003). Taking responsibility for an act not committed: Influence of age and suggestibility. Law and Human Behavior, 27, 141-156.

Rosenthal, R., \& Jacobson, L. (1968). Pygmalion in the classroom: Teacher expectation and pupils' intellectual development. New York: Holt, Rinehart, \& Winston.

Ross, L. (1977). The intuitive psychologist and his shortcomings: Distortions in the attribution process. Advances in Experimental Social Psychology, 10, 174-221. 


\section{Saul M. Kassin}

Russano, M. B., Meissner, C. A., Narchet, F. M., \& Kassin, S. M. (2005). Investigating true and false confessions within a novel experimental paradigm. Psychological Science, 16, 481-486.

Schacter, D. L. (2001). The seven sins of memory: How the mind forgets and remembers. Boston: Houghton Mifflin.

Scheck, B., Neufeld, P., \& Dwyer, J. (2000). Actual innocence. Garden City, NY: Doubleday.

Skinner, B. F. (1938). The behavior of organisms. NY: Appleton-CenturyCrofts.

Snyder, M., \& Swann, W. B., Jr. (1978). Hypothesis-testing processes in social interaction. Journal of Personality and Social Psychology, 36, 1202-1212.

Thorndike, E. L. (1911). Animal intelligence: Experimental studies. New York: MacMillan.

United States v. Belyea. U.S. Court of Appeals for the Fourth Circuit, Unpublished opinion, No. 04-4415 (2005, December 28).

Vrij, A. (2000). Detecting lies and deceit: The psychology of lying and the implications for professional practice. London: Wiley.

Vrij, A., \& Mann, S. (2001). Who killed my relative?: Police officers' ability to detect real-life high-stake lies. Psychology, Crime and Law, 7, 119-132.

Wells, G. L. (1978). Applied eyewitness-testimony research: System variables and estimator variables. Journal of Personality and Social Psychology, 30, $1546-1557$.

White, W. S. (2003). Miranda's waning protections: Police interrogation practices after Dickerson. Ann Arbor: University of Michigan Press.

Wrightsman, L. S., \& Kassin, S. M. (1993). Confessions in the courtroom. Newbury Park, CA: Sage Publications.

Zimbardo, P. G. (1967, June). The psychology of police confessions. Psychology Today, 1, 17-20, 25-27. 